\title{
STRATEGIC COOPERATION MODELS IN BUSINESS AND MILITARY ORGANIZATION
}

\author{
Lars Ehrengren \\ Stockholm University, Sweden
}

\begin{abstract}
This paper describes and explains how to make the best choice of military cooperation form based on theory from cooperation in business organizations. Negotiation, selection and choice of partner, establishment of a cooperation structure, and finally the development and management of a partnership is discussed in view of risk factor and risk control methods. To find answer to the research question(s), cooperation risk factors in business and industry was studied and analyzed in a business market war structure, developed in this project.

The result from business organizations are applied to military cooperation situations in a defined military war structure with the same approach as the business market war structure. More specific the risk factors identified in cooperation life cycle phases are examined for the two types of studied organizations and a comparison is made in the final section of the paper.
\end{abstract}

\section{INTRODUCTION}

The focus in this paper is how different kinds of cooperation relationships affect the performance of the parties involved. The aim is to find out if it is possible to increase the outcome for the parties, choosing a low risk co-operation approach instead of a high risk one. A dimension further developed in this study is the business risk aspect in a cooperation agreement negotiation. Co-operating parties could be military organizations in two countries based on a political decision or two companies competing in the same market. It could also be a combination of more than two of these possible participating organizations.

The problem area and perspectives in this paper are influenced by the present globalization, changing technologies and turbulence in the world. This paper reviews how different cooperation risk factors could be a base for analysis and follow up a cooperation agreement in different phases during the life cycle of an agreement. A cooperation risk control model for a military organization is developed based on earlier studies of Ehrengren (2006) evaluating cooperation models for business organizations. The aim with this study in broad terms is to investigate if risk control driven co-operation strategies better leverage partner expectations. Tatsiopou-los et al (2003) recent used a similar type of methodology for structured RiskManagement analysis.

After the introduction (1) and the problem discussion (2), the paper continues with a presentation of a cooperation risk control structure, which is the analytical framework in this paper (3). An overview of general studies of cooperation in different types of organizations with focus on business organizations follows (4), and thereafter I try to apply business cooperation theory to construct a cooperation risk control structure for military organizations (5).

In the analysis and result chapter, a comparison is made about cooperation risks in the two types of investigated organizations and recommendations is made to the military forces about methods to make risk evaluations in cooperation situations (6).

\section{PROBLEM DISCUSSION, AIM AND RESEARCH QUESTION}

Main purpose for this paper is to examine routines and methods when evaluating international military cooperation situations based on experience from the international business sector in order to improve the competence in this area. In general military officers should be able to conduct their units at war, but for example Swedish officers have not had that kind of experience, foremost due to the fact that Sweden has not been in a war for al-most 200 years. The military force of Sweden is under great reorganization from defence of the borders of the country to participating in international peace-keeping missions, and coalition warfare, global warfare, and high-technology warfare require soldiers who are diplomats, managers, engineers, and techno-crats as much as fighters and commanders according to Rekkedal (2003:63). In this more integrated society, the job of the soldier is becoming more interchangeable with that of his civilian counterpart than in the past.

The "principal - agent" relationship occur in many 
forms during the lifetime of a cooperation agreement. When civilian leaders delegate authority over portions of security policy to military organizations, according to Avant (1994:6), they create new political actors and the problem of agency. The military organizations may not do what politics want them to do. Research by Axelrod (1984) has shown that familiarity and frequent interaction between a small numbers of actors generally facilitates trust building and increases the likelihood of cooperation success.

Choosing the wrong motive or time perspective can lead to a co-operation failure, no matter how motivated the organizations are to collaborate. Identifying the perfect international co-operation partner is today often a very time-consuming and complicated procedure. The problem is that both business and military organizations involved in cooperation negotiations consider co-operation risk assessment too late in the negotiation and planning process. The effect is that they cannot protect themselves enough against risks that might occur during the lifetime of a co-operation. Other cooperation risks are connected to the choice of wrong time perspective or the structure of the co-operation. Higher risk increases the costs and the hazard for both parties in a co-operation arrangement.

In this study of risk assessment in military cooperation based on business cooperation, the following research questions are posted:

$\checkmark$ How is business cooperation risks managed in international operations?

$\checkmark$ What steps could be taken to improve the quality of military cooperation risks?

In research the way of generate knowledge is generally divided into three methods, deduction, induction and abduction. Deduction means that the researcher develops hypotheses based on specified theories and validates them. Induction starts in the real world and the researcher study the problem and construct thereafter pictures and models of reality. Abduction is often used when using case studies in a research situation. Using the abduction method the following steps has been taken in this study:

First: This step is necessary in order to provide a contextually informed interpretation of cooperation behave-our. This method has earlier been used by Svedin \& Bernhardsdottir in Sundelius (2004:15). Second: The time frame of the cooperation is established, and thereafter a detailed account of events is put together. By dividing the cooperation into critical time intervals and successive course of events, it is easier to analyze the case. Thirdly: This part of the analysis is focused on the cooperation opportunities and risks rather than action and decisions in themselves. This makes it possible to focus on critical cooperation decisions. The Fourth and final step is to compare the two types of organizations as a whole using the proposed cooperation risk analytical schemes.

\section{THE ANALYTICAL FRAMEWORK - A CO-OPERATION RISK CONTROL STRUCTURE}

Both domestic and international forces are important and pleas for a model that can accurately outline the interaction between domestic and international variables according to Avant (1994:2). Institutional Theory (focusing on the interaction between structure and process) provides a short cut to understanding how international and domestic variables interact and also how the interactions vary across countries. According to Runics (2000), studies reveal that when small states are confronted with international pressure during a crisis and competing values are at stake (i. e. domestic vs. international), the latter carries more weight.

When choosing form for cooperation, the main areas above can be broken down into lower levels in a strategic life cycle for short-term and long-term cooperation. Based on the theoretical study of business organizations, different risk factors can be identified for all levels of a military organization. Some risk factors are common for both business and military organizational forms, but some differ. This tool is called an

Figure 1. Business market war and military war structure: a comparison

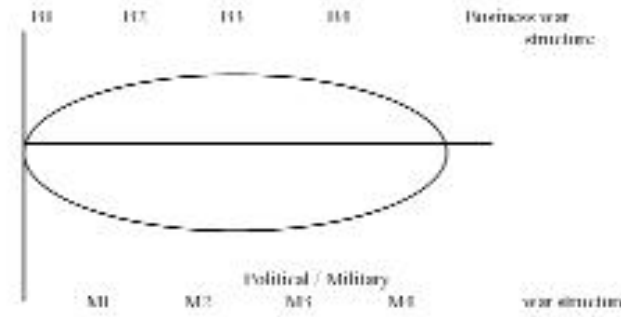

\begin{tabular}{|l|l|}
\hline $\begin{array}{l}\text { Business market } \\
\text { war structure }\end{array}$ & $\begin{array}{l}\text { Political / Military } \\
\text { war structure }\end{array}$ \\
\hline Toyota & 1.855 .886 .960 \\
\hline Oyak-Renault & 1.502 .586 .114 \\
\hline TOFAŞ* & 821.696 .368 \\
\hline Hyundai* & 223.845 .398 \\
\hline Honda Türkiye & 68.057 .862 \\
\hline
\end{tabular}


"analytical framework" in the study. Organizational learning under normal circumstances is a complex venture in itself according to Dekker \& Hansen (2004). The high degree of uncertainty may seriously impair efforts to draw lessons from business organizations and implement them in military organizations. There are great similarities between the different phases in a business market war and a military war. Both are following a certain life cycle structure. These war structures could be illustrated in the following way:

During the life length of a strategic co-operation, starting with negotiation and design and ending up with termination and evaluation of the co-operation, different kind of cooperation risks will appear. The structure of this paper is based on a life cycle concept, earlier developed by Ehrengren (2002). This concept has been further developed in this study. Another addition is a business risk factor analysis applied on short or long term forms of co-operation. This is one aspect of the cooperation, which is a basis for the comparison between risk factors in business and military organizations. The basic co-operation life cycle applied in this study mainly includes the following phases:

\section{Co-operation motives, negotiation and design \\ 2. Co-operation planning and partner selection \\ 3. Co-operation evolution and management \\ 4. Co-operation termination and evaluation}

The nature of international competition among firms has changed over the past 50 years from zero-sum com-petition to a positive sum cooperation of alliance capitalism according to Bartels and Pass (2000). To get advantage, firms are increasingly collaborating and competition and co-operation co-exist. In recent years the number of international business alliances has increased dramatically. A reason is that firms seek a global position in pursuing economies of scale and market penetration, according to Porter and Fuller (1986).

Objectives for establishing a co-operation in war structure 1 include getting access to new technologies or markets, to benefit from economies of scale in joint research, production and / or marketing. Another object-tive discussed by Ring and van de Ven (1992) is a need to obtain complementary skills by gaining access to sources of know-how located outside the firm or sharing the risk for activities that are beyond the scope or capability of a single organization. An alliance enables partners to gain the advantage of synergy between the resources, skills and competencies of the combined firms in a particular product areas as well as becoming a global player. All at lower costs and risks than doing it by oneself. Alliances enable firms to obtain member market access, technology and other skills, and launch global products in a more effective way. It is often difficult to classify a specific business co-operation, since some networks exhibit firm-like qualities like the Japanese keiretsu, whilst others are little more than instruments for the fast transmission of informal industry information. Child and Faulkner (1998) discuss some examples from high grade of integration to high grade of interdependence.

Cooperation risks to evaluate in war structure 2 when entering negotiations for a strategic co-operation include the problem of selecting the most appropriate co-operation form, and the risk that one partner fails to fulfill its obligations. According to de Wit and Meyer (1998) there is a difference between firms with a few large partners and firms with many small-scale partners. If the network is composed of a few, large alliances, the typical selection criteria are based on careful strategic considerations. There is the question of matching capabilities and resources, as well as considering the competition. Leveraging the skills of partners is easy to conceive according to Quinn (1992), but hard to implement. Trust and reciprocity are components, not substitutes to obligations. The Benetton franchising system is an extreme version of this trust system. Also Chesbrough and Teece (1996) discuss from an organization perspective, which collaboration arrangements can evolve to such an extent that a group of co-operating companies actually functions as a virtual corporation.

Important aspects for cooperation success in war structure 3 are the evolution and control over the alliance, how it is exercised and why the management of an alliance is more challenging than traditional firms. The theory on co-operation strategy draws to attention the need for the prospective partners to check that their respective strategies fit together, so that an alliance between them will make a positive contribution of the long- and short-term objectives of each cooperation partner. The co-operation business risk analysis should evaluate business risk factors such as benefits for each partner, common strengths from which both can benefit, learning as a possible result and the managerial capacity of the co-operating partners. The desires of the parents regarding input and output resources are the basic determinants of the type of strategic alliance a firm is going to enter into. Resources committed typically include physical, human, financial and organizational elements and may be provided on a limited or extensive basis. Output considerations include the extent of value added generated and how the output of the alliance is to be 
shared between the two partners. Lorange et al (1992) identified four main types of strategic alliances determined according to the parent companies input of resources and parents retrieval of output.

The evaluation in war structure 4 of the contribution of each partner in a co-operation might include factors such as the negotiating ability or the uniqueness of the assets. It is possible to identify some major challenges or obstacles that can play a key role in the success or failure of a cooperation alliance according to Lorange and Roos (1992). Five have been chosen as most relevant for strategic alliances, especially when core business are involved: (1) keep an eye on customers and competitors; (2) increase willingness to learn in order to create value from the alliance; (3) do not become dependent on a single individual or groups of individuals; (4) develop a "black box" containing the core business (technologies, markets) of the partners; (5) necessary conditions are trust and commitment. To avoid becoming"hollowed out", firms must realize how dangerous alliances can be if they not understand the motives of their partners. Without clearly understanding and identifying the risks inherent in alliances, collaboration may - according to Lei (1994), unintentionally open up the entire spectrum of the firm core competence, technologies and skills for quick learning by its partners.

\section{COOPERATION RISKS IN BUSINESS ORGANIZATIONS}

Can business risk assessment of co-operation design improve operational performance in the international business environment? One answer ware given by Kuo et al (2003), when they concluded that increased flexibility has a positive influence on the operational performance of a firm undertaking risk in an operational environment. This study is analyzing how to make the choice of cooperation form based on theory about negotiation and choice of partner, establishment of a cooperation structure, and finally the development and management of a partnership. This new business cooperation risk control model is of interest from both a theoretical and practical perspective. .

The main purpose of this section is to analyze group formation under these two opposite forces: increasing returns to size and to coordination on the one hand and heterogeneity of preferences on the other. It starts with an introduction to recent studies on network formation with bilateral relationships as its principal focus. In large range of political and economic situations a group of individuals sharing common interests can pursue them more efficiently through a coordinated action according to Demange $(2005 ; 171)$. Returns to coordinated action explain why decisions are conducted within organized groups. We try to understand which kind of cooperation among groups allows for an efficient and stable organization.

A well-developed customer strategy is not enough for long-term business success. Marketing has successively changed to market warfare. Successful strategies have to include how to handle competitors and other par-ties on the market besides a customer concept according to Durö and Sandström (1985; 9). Companies have to increase their competitor orientation, which means that the same procedures have to be used as in customer identification and analysis. Competitors have to be controlled and outmaneuvered and this is especially important on a mature market. Strategic approaches to group formation and cooperation in political and economic contexts. This includes the formation of parties, alliances among firms and informal arrangements for risk sharing in a microeconomic environment. In "Inequality and Growth Clubs", Jamarillo, Kempf and Moizeau (2005) apply coalition theory to a macroeconomic environment.

It is useful to divide the situations of group formation into categories. In the first category, almost all gains to cooperation are realized through small coalitions. Demange $(2005 ; 172)$ believe that the competitive pressure exercised by individuals ensures optimality. The second category of situations is when competition across groups is unlikely to foster the formation of small coalitions. The difference in aggregate human capital and innovations across countries is left unexplained according to Demange \& Woders $(2005 ; 10)$. This paper builds up a model, based on coalition theory, to fill this gap.

In the traditional marketing concept the customer strategy is the most dominating strategy, and in the competitor oriented market war is the competitor strategy important. The attitude against competitors is in the market war a determining factor for long-term market success, and in a business market war, the importance of allies and neutrals could be determining factors according to Durö and Sandström (1985;53).

The above model (A) shows an actor reacting real political. At high costs it demands very strong motives to take action. The (B) model shows an ideological actor. The more at stake, the lesser consideration is taken to costs. It is therefore crucial for the choice of strategy to understand the exact kind of enemy. Values and norms are important when trying to evaluate reactions and expected actions from an enemy. It is reason- 
ligure 2.
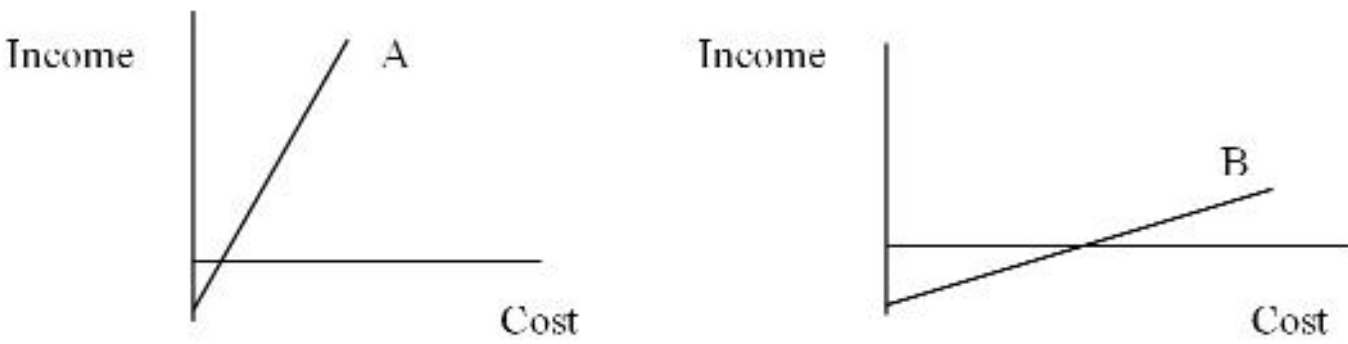

Source: Durö and Sandström (1985: 53)

able to assume that all actors would like to have a rational behavior. The problem is to understand the position of the enemy and understand what is rational from his point of view. A good help is to understand which kind of actors in principle occurs:

Other recent researcher using risk analysis on cooperation is Lee (2003). He studied strategic alliances, mergers and acquisitions in the world automobile industry, and Tatsiopoulos (2003) published a study about risk management as a strategic issue for the implementation of ERP systems. Hansèn (2002) published the result of his study related to this paper about partner selection variables in international JV:s, and Leopoulos (2003) has published the related Risk Management study about an applicable methodology for strategic risk management with a special focus on the bidding process.

Table 1. Cooperation risk factor examples in a business market war structure

\begin{tabular}{|l|l|l|}
\hline $\begin{array}{l}\text { BUSINESS MARKET } \\
\text { WAR STRUCTURE }\end{array}$ & $\begin{array}{l}\text { COOPERATION } \\
\text { CYCLE PHASE }\end{array}$ & $\begin{array}{l}\text { BUSINESS RISK FACTOR } \\
\text { EXAMPLES }\end{array}$ \\
\hline B 1 & CO-OPERATION & - REDUCE OPERATING COSTS \\
INTRODUCTION & NEGOTIATION & - LOWER R \& D COSTS \\
\hline B 2 & CO-OPERATION & - GAIN LOCAL ASSETS \\
EXPANSION & COMMITMENT & - BENEFITS FOR BOTH PARTIES \\
\hline B 3 & CO-OPERATION & - CONTINUED LEARNING \\
STAGNATION & EVOLUTION & -AVOID PARTNER COMPETITION \\
\hline B 4 & CO-OPERATION & - CO-OPERATION EXPERIENCE \\
LIQUIDATE & TERMINATION & - PARTNERSHIP COMPLEXITY \\
\hline
\end{tabular}

This model is a further development of a study by Ehrengren (2002). More specifically, the risk related conditions behind the choice between venture and alliance was examined in that study. In this new study, an analytical scheme will be developed and a comparison of cooperation risk control between cooperation in business and military organizations will be made.

\section{COOPERATION RISKS IN MILITARY ORGANIZATIONS}

Violent conflicts and wars are major obstacles to development and because of that it is important that actors in the field of military cooperation work in a way that strengthens capacities for peace. For that reason this report has the aim of combine and discusses experience gained from cooperation risk control in business organizations that can be useful in planning and execution of international military cooperation. Politics is steering, the war only a tool and not the opposite. It is obvious that the highest management level for war and where the main decisions are taken cannot be other than the political level according to Clausewitz (1991/ 2002). He also indicates that during the next decades we will see an increased international military co-operation - at least in the western world.

Armed conflicts have changed since the end of the Cold War according to Akerlund (2005):

1. Armed conflicts in the world are mostly intrastate

2. The Cold war has been replaced by an extended concept of security

3. New conclusions on the role of ethnicity and reli gion in conflicts

4. New findings on the relationship between democra cy and peace

5. Greater involvement by civil society for support of the people

Military cooperation can be developed and refined in various ways. Putting empirical cases into the analytical framework can be a first step towards the formulation of clear military cooperation strategy. One of the most important factors in classic military strategy has al-ways been the ability to faster than the enemy understand the changed preconditions and because of 
that be able to understand the effect of new factors.

In this paper about business and military cooperation strategy, I have chosen to see the problem from the total strategic perspective from the top leaders horizon of involving in political, diplomatic and military areas. The reason is that a military cooperation strategy is hard to understand if it is narrowed only to strictly military aspects and many important factors will be left out. Under politics is the total strategy, which coordinates all other strategies for different areas. Beaufre $(2002 ; 128)$ argues that military strategy is only one of these strategies. He defines the direct strategy when the military strength is the primary factor and the indirect strategy when the military force has to give space to other strategic solutions. A central problem area about using war power is to decide success criteria according to Rekkedal (1992).

Institutional theory assumes that actors will behave so as to ensure (or enhance) their institutional power. Thus, we should expect according to Avant (1994; 2) that military organizations would be responsive to civilian goals when military leaders believe that they will be rewarded for that responsiveness. Whether military leaders expect to be rewarded or not will depend on how civilian leaders have chosen to set up and monitor military organizations. The civil-military relationship is a two-tiered relationship of delegation according to Moe (1990), where voters (sometimes organized in interest groups) delegate power to civilian leaders who then delegate a portion of that power to military organizations. Andersson (2001; 4) explains the role-conflict that Swedish officers are facing during international peacekeeping operations.

It is normally great annuity about the reasons for a war, both internally in a country, between nations or between alliance partners according to Rekkedal (2003; 5). This is important as the development goes in the direction to more international operations where all parts of the military organization participate in what is called joint operations. A common development in all the Nordic states - and also in most of the other European states - is according to Arteus \& Zetterberg $(1998 ; 12)$ - that the defense policy has in the last few years become much less "reactive" (designed for meeting direct threats against the countries territory) in character and is successively becoming more "active" or preventive oriented One farreaching and rather important consequence of this development is the simple practical need to increase interoperability as much as possible between the different national de-fence forces concerned. This gives a strong impetus to extend and more effective coopera- tion between the defense planners and defense industries of the countries involved.

The issue of cooperation and coordination between the United Nations and the European regional security organizations as well as between the regional organizations themselves is currently taking on new dimensions according to Graeger \& Novosselloff $(2003 ; 75)$. The building of capacities for civilian and military action by the European Union reflects the Unions political desire to assert its profile on the international scene and influence world politics. Samii \& Sing Sidu $(2003 ; 255)$ discuss how new initiatives for regionalized capacity development have bolstered the global architecture for crisis management, and also that such developments create a higher degree of decentralization. The following factors are important in order to clarify important military problem identification and solutions according to Rekkedal (2003; 14):

$\checkmark$ Frame factors like society development, economy, norms $(=$ acceptable military and political problem definitions)

$\checkmark$ Actual technology, organization, military traditions and military capacity

$\checkmark$ How to achieve political and strategic goals. Criteria based on culture and tradition and other non-material factors.

Table 2. Cooperation risk factor examples in a political / military war structure

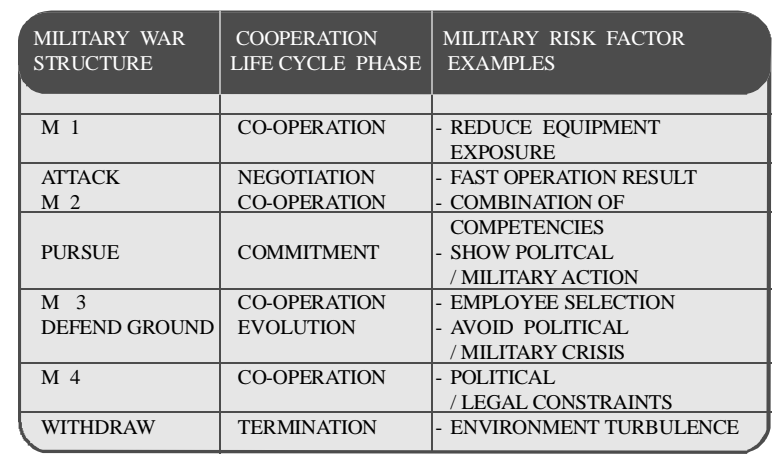

\section{COMPARISON OF COOPERATION RISK FACTORS}

In this concluding section the research question raised in the introductory section is examined, and finally a number of propositions for further research on cooperation risk control in military operations are presented. This report produced by the study is descriptive, analytical and aims to provide an analytical tool for analyses of the different cooperation risk stages in an inter- 
Table 3. Risk factor examples in business cooperation and military cooperation: a comparison

\begin{tabular}{|l|l|l|l|}
\hline $\begin{array}{l}\text { WAR } \\
\text { STRUCTURE }\end{array}$ & $\begin{array}{l}\text { COOPERATION } \\
\text { LIFE CYCLE PHASE }\end{array}$ & $\begin{array}{l}\text { BUSINESS COOPERATION RISK } \\
\text { FACTOR EXAMPLES }\end{array}$ & $\begin{array}{l}\text { POLITICAL/MILITARY COOPERATION } \\
\text { RISK FACTOR EXAMPLES }\end{array}$ \\
\hline B 1 AND M 1 & $\begin{array}{l}\text { CO-OPERATION } \\
\text { NEGOTIATION }\end{array}$ & $\begin{array}{l}\text { - REDUCE OPERATING COSTS } \\
\text { - LOWER R \& D COSTS }\end{array}$ & $\begin{array}{l}\text { - REDUCE EQUIPMENT EXPOSURE } \\
\text { - FAST OPERATION RESULT }\end{array}$ \\
\hline B 2 AND M 2 & $\begin{array}{l}\text { CO-OPERATION } \\
\text { COMMITMENT }\end{array}$ & $\begin{array}{l}\text { - GAIN LOCAL ASSETS } \\
\text { - BENEFITS FOR BOTH PARTIES }\end{array}$ & - COMBINATION OF COMPETRENCES \\
& - SHOW POLITICAL/MILITARY ACTION \\
\hline B 3 AND M 3 & $\begin{array}{l}\text { CO-OPERATION } \\
\text { EVOLUTION }\end{array}$ & $\begin{array}{l}\text { - CONTINUED LEARNING } \\
\text { - AVOID PARTNER COMPETITION }\end{array}$ & - AVOID POLITICAL/MILITARY CRISIS \\
\hline B 4 AND M 4 & CO-OPERATION & - CO-OPERATION EXPERIENCE & - ENVIRONMENT TURBULENCE \\
& TERMINATION & - PARTNERSHIP COMPLEXITY & - POLITICAL/LEGAL CONSTRAINTS \\
\hline
\end{tabular}

national military joint mission based on cooperation risks in an international collaboration between two business corporations. The study ends with a comparison of risk factors in the two studied types of organizations, with some recommendations for parties involved. Some suggestions for further research conclude the paper.

The first research question was how cooperation risks are managed in business and military international operations. In order to analyze this question, a business war structure (B1 - B4) and a political/military war structure (M1 - M4) was identified. With this instrument it was possible to make comparisons between the different life cycle phases during the war structure. The cooperation conditions differ radically between the two types of organizations. In business collaborations the choice of partner is often a choice between more than one and there is time available for negotiating about the cooperation conditions. The theoretical aspects on cooperation risks in four defined war structures have been described and are represented in the risk factor schemes defined for both business cooperation and political/military cooperation. In the political/military case the choice of partner is seldom a reality, and there is most often no time for negotiations about minimizing or elimination of cooperation risks. The most experienced of the partners have the informal power to decide about the most critical parts in the cooperation agreement. The answer is that no routines or standard procedures for defining, analyzing or evaluation of cooperation risks either in business or in military co-operation could be found

The second research question was what steps could be taken to improve the quality of political / military cooperation risks. In order to answer this question, cooperation life cycle phases was identified for business market war structures and for political/military war structures: cooperation negotiation, cooperation commitment, cooperation evolution and finally cooperation termination. For each life cycle phase two examples of risk factors has been identified for business cooperation (table 1) and for military cooperation (table 2):
One conclusion is that with the help of identified cooperation risk factors a base is created for identifying early warning signals based on cooperation risk factors could be developed. The importance of contribution of this type cannot be underestimated, since war and conflicts (both business and military) have seldom winners - but often losers. It is my anticipation that managers in international business and military organizations will improve the possibility to take advantage of cooperation opportunities and those teachers and students will gain knowledge from the approach taken in this paper.

One area for further research is to analyze risk factors in short-term cooperation and in long time cooperation. Another area for further research is to examining real cases and testing the proposed cooperation risk factors during the cooperation life cycle in some real war cases. I believe that this recommended study with analysis of real cases would be useful for a wide range of civil and military organizations. 


\section{REFERENCES}

Andersson, L. (2001), Militärt ledarskap - när det gäller. Doctoral dissertation, The Swedish Defence College, Karlstad, Sweden (in Swedish)

Arteus, G and Zetterberg, K (Eds). (1998), Försvarspolitik I Norden - eller nordisk försvarspolitik?. Försvarshögskolan, Strategiska institutionen, ACTA B8, Stockholm, Sweden (in Swedish)

Avant, D. (1994), Political institutions and Military change. Cornell university Press, U.S A

Axelrod, R. (1984), The evolution of cooperation. New York, basic Books Inc, U S A

Beaufre, A. (2002), Modern strategi för fred och krig. Prisma, Militärlitteraturföreningen nr 241, Göteborg, Sweden, p 127 (in Swedish)

Bartels, F \& Pass, C. (2000), International Business a competitiveness approach", Prentice Hall, Singapore.

Child, J and Faulkner, D. (1998), The strategies of co-operation - managing Alliances, Networks and Joint Ventures. Oxford University Press, New York, USA

Clausewitz, C von. (1991/2002), Om kriget.

Bonniers, Stockholm, Sweden (in Swedish)

Dekker, S and Hansen, D. (2004), Learning under pressure: The effects of Politicization on organizational learning in Public Bureaucracies. Journal of Public Administration Research. No 14:2, p 211-230

Demange, G.(2005), Group formation. In Demange, G. \& Wooders, M: Group Formation in Economics, Cambridge University Press, and Cambridge, United Kingdom.

Demange, G \& Wooders, M. (2005), Group Formation in Economics, Cambridge University Press, Cambridge, United Kingdom.

De Wit, B \& Meyer, R. (1994), Strategy -an international perspective. West Publ Co, St Paul, USA

Durö, R \& Sandström, B. (1985),

Marknadskrigföring. LiberFörlag, Malmö, Sweden (in Swedish)

Ehrengren, L. (2002), International Strategic

Business Cooperation - in Alliance or Joint venture? in Larimo, $\mathbf{J}$ (ed.). Current European Research in International Business, Vaasa University Press, Vaasa, Finland

Ehrengren, L. (2006), Risk related global production flexibility". International Journal of Business Environment. Inderscience Publ., Geneva, Switzerland

Graeger, P and Novosseloff, A. (2003), The Role of the OSCE and the EU in Pugh, M and Sing W: The United Nations and Regional Security - Europe and Beyond. International Peace Academy. Rienners Publ, London, Great Britain

Hansén, S-O. (2002), Partner selection in international JV:s selection variables for strategic long term fit. Paper presented at the International small business Conference in Kuopio, Finland .

Jamarillo,F and Kempf, H and Moizeau, F. (2005), Inequality and Growth Clubs. In Demange, G. \& Wooders, M: Group Formation in Economics, Cambridge University Press, Cambridge, United kingdom.

Kuo, H-C \& Li, Y \& Ting, M. (2003), Can flexibility improve operational performance? International Journal of Risk Assessment and Managemet, vol 4, No 4, p 263. Inderscience Publ., Geneva, Switzerland Lee, H-S. (2003), Strategic alliance, Mergers and Acquisitions in the world automobile industry. Paper presented at the GBATA International Conference in Budapest, Hungary.

Lei, D and Slocum, J W Jr. (1992), Global strategy, Competence-building and Strategic alliances, California Management Review, Fall, p 81-99.

Leopoulos, V \& Kirytopoulos,K \& Malandrakis,C. (2003), An applicable methodology for strategic risk management during the bidding process.

International Journal of Risk Assessment and

Management, Vol. 4, No. 1, p. 67. Inderscience Publ., Geneva, Switzerland

Lorange, P, Roos, J and Brönn, P S.(1992), Building successful strategic alliances, Long Range Planning, vol 25, no 6, p $10-17$

Lorange, P and Roos, J. (1992), Strategic Alliances Formation, Implementation and Evolution. Blackwell Publ Inc. Cambridge, MA, USA

Moe, T. (1990), The Politics of Structural Choice. In 
Williamson, O: Organizational Theory. Oxfort university Press, N Y, U S.

Porter, M. (1985), Competitive Advantage, The Free Press, New York, USA

Porter, M and Fuller, M. (1986), Coalitions and global strategy, in Porter, M (ed): Competition in global industries. Harvard Business School Press. Boston MA, USA

Rekkedal, N. (2003), Modern Krigskonst Militärmakt i förändring. Försvarshögskolan, Stockholm, Sweden. (in Swedish)

Ring, P S and van de Ven, A H. (1992), Structuring cooperative relationships between organizations, Strategic Management Journal, vol. 13, p 483-498.

Runics, A. (2000), The citizenship Issue as a Creeping Crisis" in Stern,E and Hansen, D (Eds) :Crisis management in a transitional society - The Latvian example, pp 61-97 Stockholm: The National Defence College of Sweden

Samii, C and Sing Sidhu, W. (2003), Strengthening Regional Approaches to Peace Operations, in Pugh, $\mathrm{M}$ and Sing Sidu, W : The United Nations and Regional Security - Europe and Beyond. International Peace Academy, Rienners Publ, London, Great Britain

Singleton, R. jr Et al. (1988), Approaches to social research. Oxford University Press, N Y, USA

Svedin, L and Bernhardsdottir, A. (2004), Small State crisis management, in Sundelius, B (Ed): Crisis Management Europe Research Program Publications, Stockholm, Sweden

Tatsiopoulos, I \& Panayiotou, N \& Kirytopoulos, K \& Tsitsiriggos,K. (2003), Risk Management as a strategic issue for the implementation of ERP systems. International. Journal of Risk Assessment and Management, Vol 4, No 1, p 20. Inderscience Publ., Geneva, Switzerland 